\section{Court victory for subject of experimental therapy}

Dieter Bollmann of Berlin, who underwent unsuccessful stem-cell therapy for urinary incontinence, has won a court case against authorities of the University Hospital Innsbruck in Austria. He had claimed that the urologists who treated him had not told him the procedure was experimental.

On 11 July, a civil court awarded Bollmann nearly $€ 3,000$ (US $\$ 4,800$ ) in damages and expenses. His lawyer is considering claims from several other former patients who were similarly operated on within the past few years.

The therapy involves generating muscle stem cells from a biopsy taken from a patient's arm, then injecting them into the same patient's urinary sphincter in an attempt to boost its contractile power. The urologists are also involved in an independent dispute with their local ethics committee, which claims they carried out clinical trials - one of which was published in The Lancet - without ethics approval (see Nature 453, 6-7 and 1177; 2008).

\section{Drug firms join forces to boost discovery pipeline}

Pharmaceutical giants Merck, Pfizer and Eli Lilly have joined forces in a start-up company that they hope will stimulate drug discovery.

Boston-based Enlight Biosciences will develop lab technologies to the 'pre-competitive' stage, so that each company will be able to use them to take its own research forward. The firm's leaders include a coalition of drug-development and academic researchers, such as Robert Horvitz, a Nobel laureate biologist at the Massachusetts Institute of Technology in Cambridge.

Enlight will focus on areas such as imaging technologies, toxicology studies and speeding up the synthesis of interesting compounds. Relatively little money has been committed so far - just \$39 million has been announced to target these areas and many more.

\section{Chemical giant seeks route into speciality market}

US chemical company Dow is buying out rivals Rohm and Haas for more than $\$ 15$ billion.

The move is part of an attempt by Dow, which is headquartered in Midland, Michigan, to move into speciality chemicals and away from the bulk products that have traditionally made up its business. The acquisition of Rohm and Haas, based in Philadelphia, Pennsylvania, would make Dow the largest speciality chemicals firm in the United States, according to company officials.

Dow will pay \$78 per Rohm and Haas share, a substantial premium on stock that was trading at around $\$ 45$ before the announcement.

\section{'Fundamentally flawed' US pollution law thrown out}

A US appeals court struck down landmark air-pollution regulations last week, shocking both environmental and industry groups with a decision that could severely hamper efforts to curb smog and acid rain.

\title{
Lionfish not a roaring success for coral reefs
}

The red lionfish (Pterois volitans), a stunning Indo-Pacific species, is central to an invasive-species worst-case scenario that is playing out in the Atlantic Ocean. A study suggests that lionfish, with their voracious appetites, can reduce the survival of young fish on experimental reefs by $80 \%$.

Eradicating the lionfish is now all but impossible in the Bahamas, warn the study's researchers. But conservationists in nearby regions in which lionfish have been spotted in smaller numbers, such as the Dominican Republic, could take steps to guard against the interlopers while there is still time. The study was presented last week at an international corals conference in Fort Lauderdale, Florida.

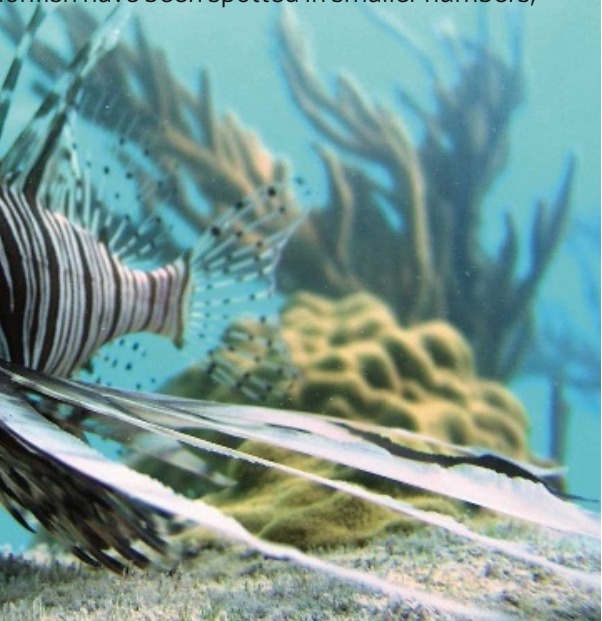

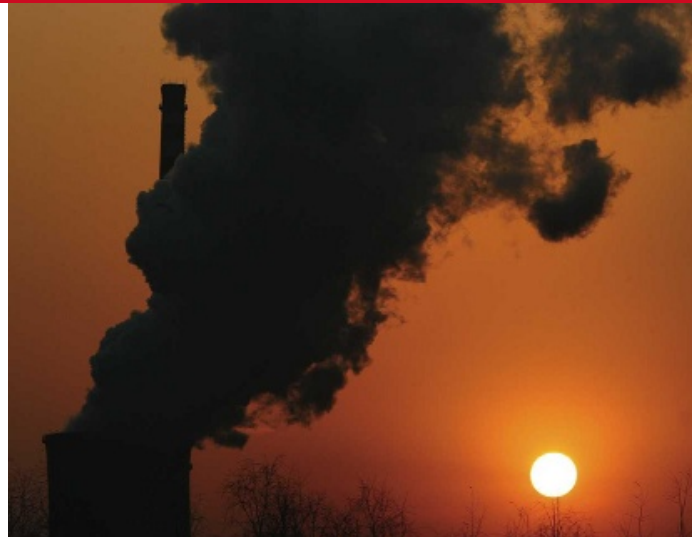

Efforts to curb pollution in the United States have suffered a legal set-back.

The 2005 Clean Air Interstate Rule created a market-based programme allowing utilities to buy and sell permits in order to meet new limits set for emissions of sulphur dioxide and nitrogen oxides. Many within the utility industry supported the programme, but North Carolina and a number of power companies challenged various aspects of the law, including how the permits were distributed. The court agreed, calling the programme "fundamentally flawed" and ordering the Environmental Protection Agency (EPA) to start anew.

The decision came on the same day that the EPA said it would delay issuing the regulations on how to deal with carbon dioxide emissions that the Supreme Court had demanded.

For a longer version of this story, see http://tinyurl.com/6pafqx

\section{FDA aims for neutral tone in drug-rejection letters}

In a move intended to stop investors from over-interpreting its decisions, the US Food and Drug Administration (FDA) will next month adopt a new system for delivering less-than-stellar news to companies trying to bring new drugs to market.

From 11 August, the agency will stop sending out its current genre of missives, which come in two categories: 'approvable' letters, if the drug needs more information or specific changes to win approval, and 'not approvable' letters, for applications with more major problems. In their place, a company whose drug is being rejected will receive a 'complete response' letter outlining an application's deficiencies and what can be done to address them.

Because the letters are private, investors will be able to infer little from a complete response except that a drug hasn't yet met the FDA's marketing standards. The change, says Janet Woodcock, the agency's top drugapproval official, will help the FDA to adopt "a more consistent and neutral way" of delivering the news that a drug application is not up to standard. 